\title{
PENJADWALAN PROYEK MESIN AUTO ASSEMBLY MEMBRANE REGULATOR VALVE DI PT. OMG METODE CRITICAL PATH METHOD (CPM)
}

\author{
Popy Yuliarty), Rini Anggraini' ${ }^{2)}$,Tri Wastiono ${ }^{3)}$ \\ ${ }^{1,3)}$ Prodi Teknik Industri, Universitas Mercu Buana, jl.Meruya Selatan No.1 Kembangan Jakbar \\ ${ }^{2}$ Prodi Teknik Mesin, Universitas Mercu Buana, jl.Meruya Selatan No.1 Kembangan Jakbar \\ popy.yuliarty@mercubuana.ac.id
}

\begin{abstract}
Abtrak, Kemajuan Teknologi Industri di Indonesia menuntut adanya perubahan positif yang mengarah pada sistem automasi di semua industri. PT. Oto Makmur Gemilang (OMG) adalah perusahaan yang bergerak dalam industri jasa machine maker otomation and robotic. Dalam menjalankan proyeknya PT. OMG belum memiliki metode khusus untuk melakukan penjadwalan guna mendapatkan estimasi waktu hingga terselesainya proyek dan selama ini hanya menggunakan perkiraan berdasarkan pengalaman saja. Tujuan dari penelitian ini adalah untuk menentukan waktu optimal dalam menyelesaikan proyek mesin Auto Assembly Membrane Regulator Valve Di PT. OMG. Metode Critical Path Method (CPM) digunakan untuk mengidentifikasi waktu secara realitis untuk setiap aktivitas sehingga dapat membantu menunjukkan hubungan setiap aktivitas. Tujuan yang ingin dicapai dalam peng-implementasian Metode CPM ini adalah untuk mendapatkan estimasi durasi proyek yang efisien dalam menyelesaikan proyek. Hasil akhir dari penelitian ini adalah dengan menggunakan metode CPM, proyek lebih cepat diselesaikan 42 hari ( 31.5\%) dari waktu sebelumnya yaitu 133 hari menjadi 91 hari.
\end{abstract}

Kata Kunci : Proyek, Penjadwalan, Estimasi, Metode CPM

\section{PENDAHULUAN}

Kemajuan Teknologi industri di Indonesia yang menuntut adanya perubahan dan kemajuan yang terus menerus ke arah system automasi. Kemajuan zaman dan teknologi pada dunia industri berdampak pada persaingan di industri khususnya bidang manufactur. Persaingan tersebut harus disikapi dengan kritis demi kemajuan industri manufactur. Industri modern yang dimaksud adalah adanya mekanisasi untuk merubah tenaga manusia dengan peralatan-peralatan canggih atau mesin - mesin canggih untuk mencapai tingkat peroduktivitas yang lebih baik.

Ketepatan dalam suatu projek dapat menjadikan nilai lebih bagi perusahaan dalam meningkatkan service berupa kepuasan kepada konsumen. Ketepatan dalam pelaksanaan proyek menjadikan tolak ukur oleh konsumen terhadap perusahaan pemegang proyek dalam pemberian proyek proyek berikutnya. Sehingga sebuah perusahaan yang dapat menjalankan proyek secara efektif dan efisien, akan dapat mempertahankan kelangsungan hidup dan meningkatkan mutu citra prusahaanya. PT. OMG adalah perusahaan yang bergerak dalam industri jasa machine maker otomation dan robotic. PT. OMG merupakan perusahaan joint ventur, bersama perusahaan asing di industri robotic dan otomasi dari china yaitu Dongguan Yicheng Automation Equipment Co., Ltd. PT. OMG adalah perusahaan baru yang sedang berkembang di Indonesia. PT. OMG tidak memiliki metode khusus, dalam melakukan penjadwalan untuk mendapatkan estimasi waktu hingga terselesainya proyek. Selama ini PT. OMG hanya berpedoman pada pengalaman sebelumnya dalam menjalankan dan mengerjakan proyek. Sehingga PT. OMG tidak memiliki orientasi waktu yang pasti untuk menyelesaikan proyek. Untuk menyelesaikan proyek dengan tepat, diperlukan penjadwalan proses dari hulu hingga kehilir yang mana dari proses pembuatan proposal berupa penawaran kepada konsumen hingga barang jadi (finish goods). Salah satu metode yang dapat digunakan untuk pengendalian jadwal proyek adalah dengan metode Critical Path Method (CPM), dengan menggunakan metode CPM dapat digunakan untuk mengidentifikasi waktu secara realitis untuk setiap aktivitas sehingga dapat membantu menunjukan hubungan setiap aktivitas, dengan aktifitas lainnya, serta dapat mengidentifikasi ubungan yang harus didahulukan diantara aktivitas lainya. Metode Critical Path Method (CPM) adalah metode yang berorientasi pada waktu penentuan jadwal 
dan estimasi yang bersifat pasti, sehingga hanya diperlukan satu faktor waktu untuk setiap aktivitasnya. Alasan memilih meode CPM adalah karena metode ini banyak digunakan oleh kalangan industri atau proyek konstruksi dan digunakan jika durasi pekerjaan dapat diketahui dan tidak terlalu berfluktuasi. Metode ini sudah sesuai dengahn karakteristik objek yang diteliti. Dengan adanya latar belakang tersebut maka dengan penerapan metode Critical Path Method (CPM), peneliti ingin mendapatkan waku normal serta waktu optimum penjadwalan proyek Mesin Auto Assembly Membrane Regulator Valve Di PT. OMG. Mengingat pentingnya suatu estimasi dan penjadwalan dalam menjalankan proyek maka metode cpm dapat digunakan dan diaplikasikan pada proyek yang ada di PT.OMG.

\section{METODE}

Metode diartikan sebagai cara yang tepat, kemudian penelitian adalah kegiatan ilmiah untuk memperoleh pengetahuan yang benar tentang suatu masalah. Didalam penelitian ini menggunakan model kuantitatif dan model kualitatif atau dengan kata lain model campuran. Flowchart penelitian ini dapat dilihat pada gambar 1 berikut ini :
Studi lapangan dan literatur .

Latar belakang masalah \& Tujuan Penelitian

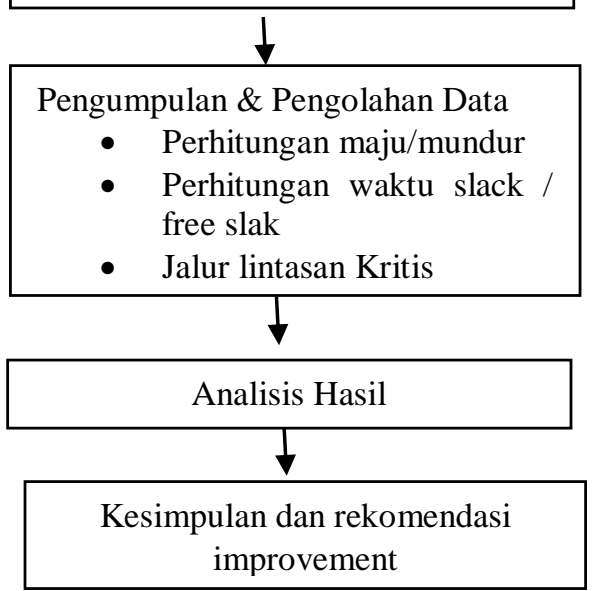

Gambar. 1. Flowchart Penelitian

\section{HASIL DAN PEMBAHASAN}

Penjadwalan berlangsung terjadi tanpa adanya acuan metode ilmiah yang digunakan, hanya berdasarakan waktu pengalaman. Dari data observasi pengamatan, wawancara karyawan dan data schedule proyek OTO didapatkan data pada Table 1 berikut ini :

Table 1. Data aktivitas kegiatan pekerjaan proyek mesin auto assembly membrane regulator valve.

\begin{tabular}{|c|c|c|c|}
\hline No & Item Pekerjaan & Kode Pekerjaan & $\begin{array}{l}\text { Kurun Waktu } \\
\text { (Hari) }\end{array}$ \\
\hline & Pekerjaan Persiapan & & \\
\hline 1 & Diskusi Proposal & A & 1 \\
\hline 2 & Proposal 1 & $\mathrm{~B}$ & 4 \\
\hline 3 & Revisi I Proposal & $\mathrm{C}$ & 4 \\
\hline \multirow[t]{2}{*}{4} & Revisi Ii Proposal & $\mathrm{D}$ & 4 \\
\hline & Detail Design & & \\
\hline 5 & Detail Design 1 & $\mathrm{E}$ & 14 \\
\hline 6 & Revisi I Detail Design & $\mathrm{F}$ & 7 \\
\hline \multirow[t]{2}{*}{7} & Revisi Ii Detail Design & $\mathrm{G}$ & 7 \\
\hline & Pembelian Material & & \\
\hline 8 & Spart Part (Import) & $\mathrm{H}$ & 21 \\
\hline \multirow[t]{2}{*}{9} & Spart Part Machining (Steel, Aluminium,Dll) & $\mathrm{I}$ & 2 \\
\hline & Machining & & \\
\hline 10 & Milling & $\mathrm{J}$ & 14 \\
\hline 11 & Wirecut & $\mathrm{K}$ & 7 \\
\hline 12 & Las Body & $\mathrm{L}$ & 7 \\
\hline 13 & Grinding & $\mathrm{M}$ & 10 \\
\hline 14 & Bubut & $\mathrm{N}$ & 6 \\
\hline 15 & Cnc & $\mathrm{O}$ & 2 \\
\hline \multirow[t]{2}{*}{16} & Chrome Spart Part Machining & $\mathrm{P}$ & 4 \\
\hline & Assembly & & \\
\hline
\end{tabular}




\begin{tabular}{|l|l|c|c|}
\hline \hline 17 & Assembly Mechanik Spart Paart & Q & 4 \\
\hline 18 & Instalation Kabel (Wiring) & R & 4 \\
\hline 19 & Programming Mesin & S & 6 \\
\hline & Trial & & \\
\hline 20 & Trial 1 & T & 1 \\
\hline 21 & Trial 2 & U & 1 \\
\hline 22 & Finishing & V & 1 \\
\hline 23 & Shipping & W & 2 \\
\hline
\end{tabular}

Pada Tabel 1 diatas merupakan penjadwalan waktu 23 kegiatan pekerjaan untuk menyelesaikan proyek mesin auto assembly membrane regulator valve. Waktu yang digunakan adalah waktu normal dimana pekerjaan dapat dilakukan dan membutuhkan waktu yang wajar dan tidak terdapat kendala untuk menyelesaikannya. Selanjutnya adalah membuat predesesor. Predesesor adalah sebuah tabel yang menerangkan setiap kegiatan yang didahului dan kegiatan yang mendahului, atau bisa disebut dengan hubungan kegiatan. Predesesor ini berguna untuk perencanaan proyek agar proyek yang dijalankan bisa sesuai perencanaan yang baik. Tabel predesesor atau hubungan kegiatan proyek bisa dilihat pada Tabel 2 dibawah ini:

Table 2. Hubungan kegiatan proyek mesin auto assembly membrane regulator valve.

\begin{tabular}{|c|c|c|c|}
\hline No & ITEM PEKERJAAN & KODE PEKERJAAN & PREDESESOR \\
\hline & PEKERJAAN PERSIAPAN & & \\
\hline 1 & DISKUSI PROPOSAL & A & \\
\hline 2 & PROPOSAL 1 & B & A \\
\hline 3 & REVISI I PROPOSAL & $\mathrm{C}$ & B \\
\hline \multirow[t]{2}{*}{4} & REVISI II PROPOSAL & D & $\mathrm{C}$ \\
\hline & DETAIL DESIGN & & \\
\hline 5 & DETAIL DESIGN 1 & E & D \\
\hline 6 & REVISI I DETAIL DESIGN & $\mathrm{F}$ & $\mathrm{E}$ \\
\hline \multirow[t]{2}{*}{7} & REVISI II DETAIL DESIGN & G & $\mathrm{F}$ \\
\hline & PEMBELIAN MATERIAL & & \\
\hline 8 & SPART PART (IMPORT) & $\mathrm{H}$ & G \\
\hline \multirow[t]{2}{*}{9} & $\begin{array}{l}\text { SPART PART MACHINING (STEEL, } \\
\text { ALUMINIUM,DLL) }\end{array}$ & I & $\mathrm{H}$ \\
\hline & MACHINING & & \\
\hline 10 & MILLING & $\mathrm{J}$ & I \\
\hline 11 & WIRECUT & $\mathrm{K}$ & I \\
\hline 12 & LAS BODY & $\mathrm{L}$ & I \\
\hline 13 & GRINDING & M & I \\
\hline 14 & BUBUT & $\mathrm{N}$ & I \\
\hline 15 & $\mathrm{CNC}$ & $\mathrm{o}$ & I \\
\hline \multirow[t]{2}{*}{16} & CHROME SPART PART MACHINING & $\mathrm{P}$ & $\mathrm{J}, \mathrm{K}, \mathrm{L}, \mathrm{N}, \mathrm{O}$ \\
\hline & ASSEMBLY & & \\
\hline 17 & ASSEMBLY MECHANIK SPART PAART & Q & $\mathrm{P}$ \\
\hline 18 & INSTALATION KABEL (WIRING) & $\mathrm{R}$ & $\mathrm{H}$ \\
\hline \multirow[t]{2}{*}{19} & PROGRAMMING MESIN & $\mathrm{s}$ & $\mathrm{Q}, \mathrm{R}$ \\
\hline & TRIAL & & \\
\hline 20 & TRIAL 1 & $\mathrm{~T}$ & $\mathrm{~s}$ \\
\hline 21 & TRIAL 2 & $\mathrm{U}$ & $\mathrm{T}$ \\
\hline 22 & FINISHING & $\mathrm{V}$ & $\mathrm{U}$ \\
\hline 23 & SHIPPING & w & $\mathrm{v}$ \\
\hline
\end{tabular}


Selanjutnya kegiatan tersebut dapat digambarkan dalam suatu bentuk diagram jarigan kerja pada Gambar 2 berikut ini :

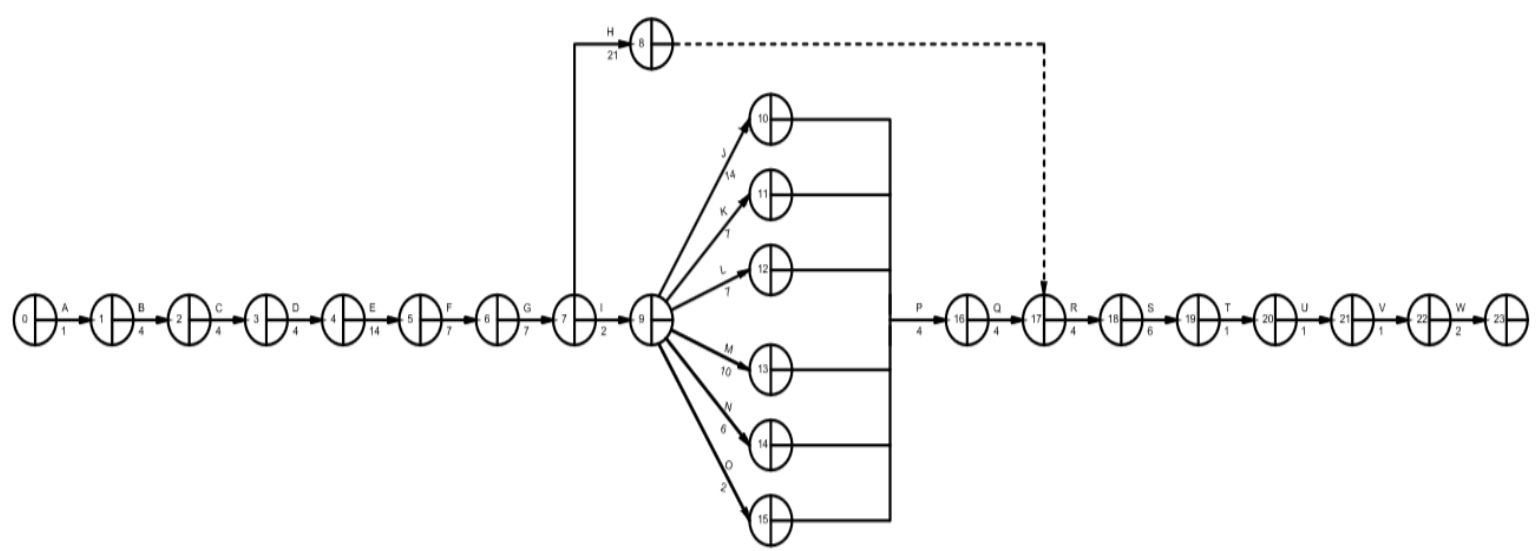

Gambar 2. Network hubungan kegiatan proyek mesin auto assembly membrane regulator valve.

\section{Perhitungan Maju}

Perhitungan maju dalam proyek ini dimaksudkan untuk mengidentifikasi jalur kritis. Tabel 3 berikut ini adalah data perhitungan maju dari pelaksanaan proyek mesin auto assembly membrane regulator valve.

Table 3. Perhitungan Maju

\begin{tabular}{|c|c|c|c|c|c|c|}
\hline \multicolumn{3}{|r|}{ KEGIATAN } & \multirow{2}{*}{ KODE PEKERJAAN } & \multirow{2}{*}{$\begin{array}{c}\text { KURUN WAKTU } \\
\text { (HARI) } \\
\text { t (hari) }\end{array}$} & \multicolumn{2}{|c|}{$\begin{array}{c}\text { WAKTU PALING AWAL } \\
\text { (MAJU) }\end{array}$} \\
\hline i & $\mathbf{j}$ & ITEM PEKERJAAN & & & MULAI (ES) & $\begin{array}{c}\text { SELESAI (EF) } \\
(\text { (EF=ES+t) }\end{array}$ \\
\hline & & PEKERJAAN PERSIAPAN & & & & \\
\hline 1 & 2 & DISKUSI PROPOSAL & A & 1 & 0 & 1 \\
\hline 2 & 3 & PROPOSAL 1 & B & 4 & 1 & 5 \\
\hline 3 & 4 & REVISI I PROPOSAL & $\mathrm{C}$ & 4 & 5 & 9 \\
\hline 4 & 5 & REVISI II PROPOSAL & $\mathrm{D}$ & 4 & 9 & 13 \\
\hline & & DETAIL DESIGN & & & & \\
\hline 5 & 6 & DETAIL DESIGN 1 & $\mathrm{E}$ & 14 & 13 & 27 \\
\hline 6 & 7 & REVISI I DETAIL DESIGN & $\mathrm{F}$ & 7 & 27 & 34 \\
\hline 7 & 8 & REVISI II DETAIL DESIGN & G & 7 & 34 & 41 \\
\hline & & PEMBELIAN MATERIAL & & & & \\
\hline 8 & 9 & SPART PART (IMPORT) & $\mathrm{H}$ & 21 & 41 & 62 \\
\hline 9 & 10 & $\begin{array}{l}\text { SPART PART MACHINING } \\
\text { (STEEL, ALUMINIUM,DLL) }\end{array}$ & I & 2 & 42 & 44 \\
\hline & & MACHINING & & & & \\
\hline 10 & 11 & MILLING & $\mathrm{J}$ & 14 & 44 & 58 \\
\hline 11 & 12 & WIRECUT & $\mathrm{K}$ & 7 & 44 & 51 \\
\hline 12 & 13 & LAS BODY & $\mathrm{L}$ & 7 & 44 & 51 \\
\hline 13 & 14 & GRINDING & M & 10 & 58 & 68 \\
\hline
\end{tabular}




\begin{tabular}{|c|c|l|c|c|c|c|}
\hline 14 & 15 & BUBUT & N & 6 & 44 & 50 \\
\hline 15 & 16 & CNC & O & 2 & 44 & 46 \\
\hline 16 & 17 & $\begin{array}{l}\text { CHROME SPART PART } \\
\text { MACHINING }\end{array}$ & P & 4 & 68 & 72 \\
\hline 17 & 18 & ASSEMBLY MECHANIK SPART P & Q & 4 & 72 & 76 \\
\hline 18 & 19 & INSTALATION KABEL (WIRING) & R & 4 & 76 & 80 \\
\hline 19 & 20 & PROGRAMMING MESIN & S & 6 & 80 & 86 \\
\hline & & TRIAL & T & 1 & 86 & 87 \\
\hline 20 & 21 & TRIAL 1 & U & 1 & 87 & 88 \\
\hline 21 & 22 & TRIAL 2 & V & 1 & 88 & 89 \\
\hline 22 & 23 & FINISHING & W & 2 & 89 & 91 \\
\hline 23 & 24 & SHIPPING & & & & \\
\hline
\end{tabular}

Tabel 3 adalah tabel perhitungan maju, contoh perhitungan maju adalah operasi pertama pada kegiatan A memiliki waktu mulai (start) awal (ES) adalah 0, waktu selesai (finish) awal untuk aktivitas $\mathrm{A}$ adalah 1 yang mana berasal dari rumus $(\mathrm{EF}=\mathrm{ES}+\mathrm{D}$ atau $\mathrm{EF}=0+$ $1=1$ ). Demikian untuk kegiatan $B$ memiliki waktu mulai (start) awal (ES) adalah 1, waktu selesai (finish) awal untuk aktivitas B adalah 5 yang mana berasal dari rumus $(\mathrm{EF}=\mathrm{ES}+\mathrm{D}$ atau $\mathrm{EF}=1+4=5$ ). Selanjutnya kegiatan tersebut dapat digambarkan dalam suatu bentuk diagram jarigan kerja sebagai berikut :

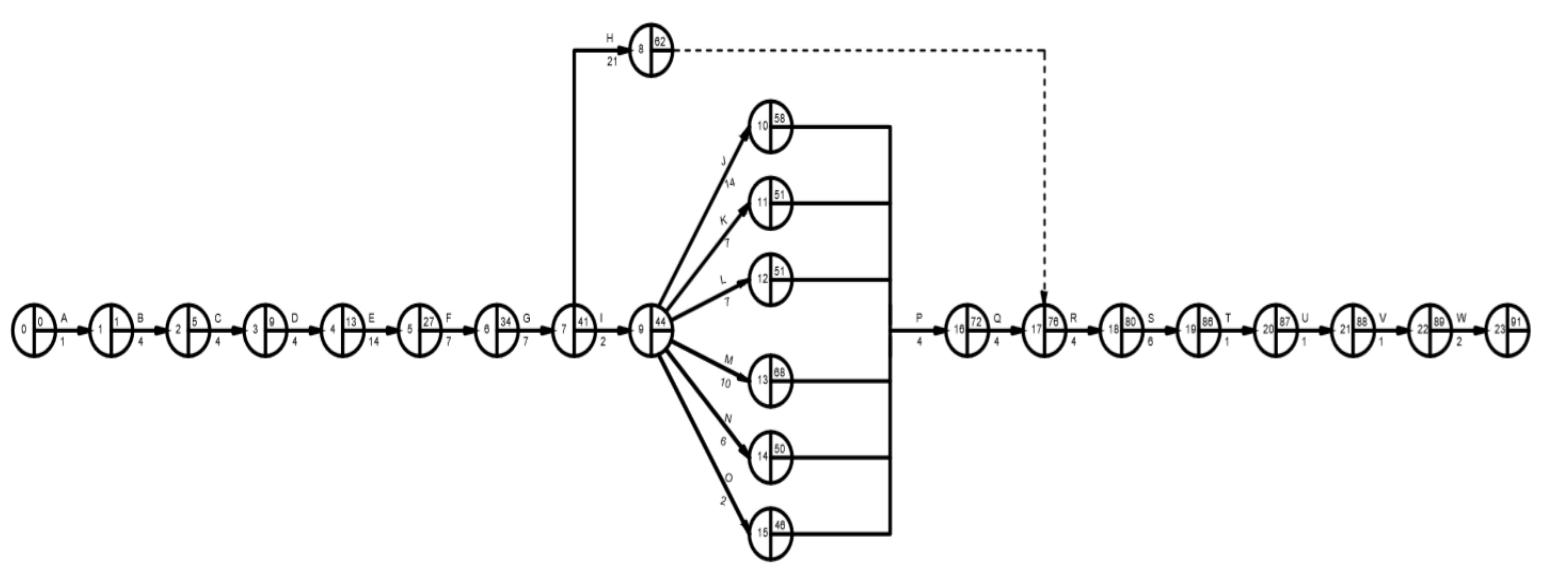

Gambar 3. network perhitungan maju proyek mesin auto assembly membrane regulator valve

\section{Perhitungan Mundur}

Perhitungan mundur dalam proyek ini dimaksudkan untuk mengetahui waktu atau tanggal paling akhir, untuk dapat memulai dan mengakhiri masing - masaing kegiatan tanpa menunda kurun waktu penyelesaian proyek secara keseluruhan. Berikut ini adalah perhitungan mundur pelaksanaan proyek mesin auto assembly membrane regulator valve: 
Table 4. Perhitungan Mundur

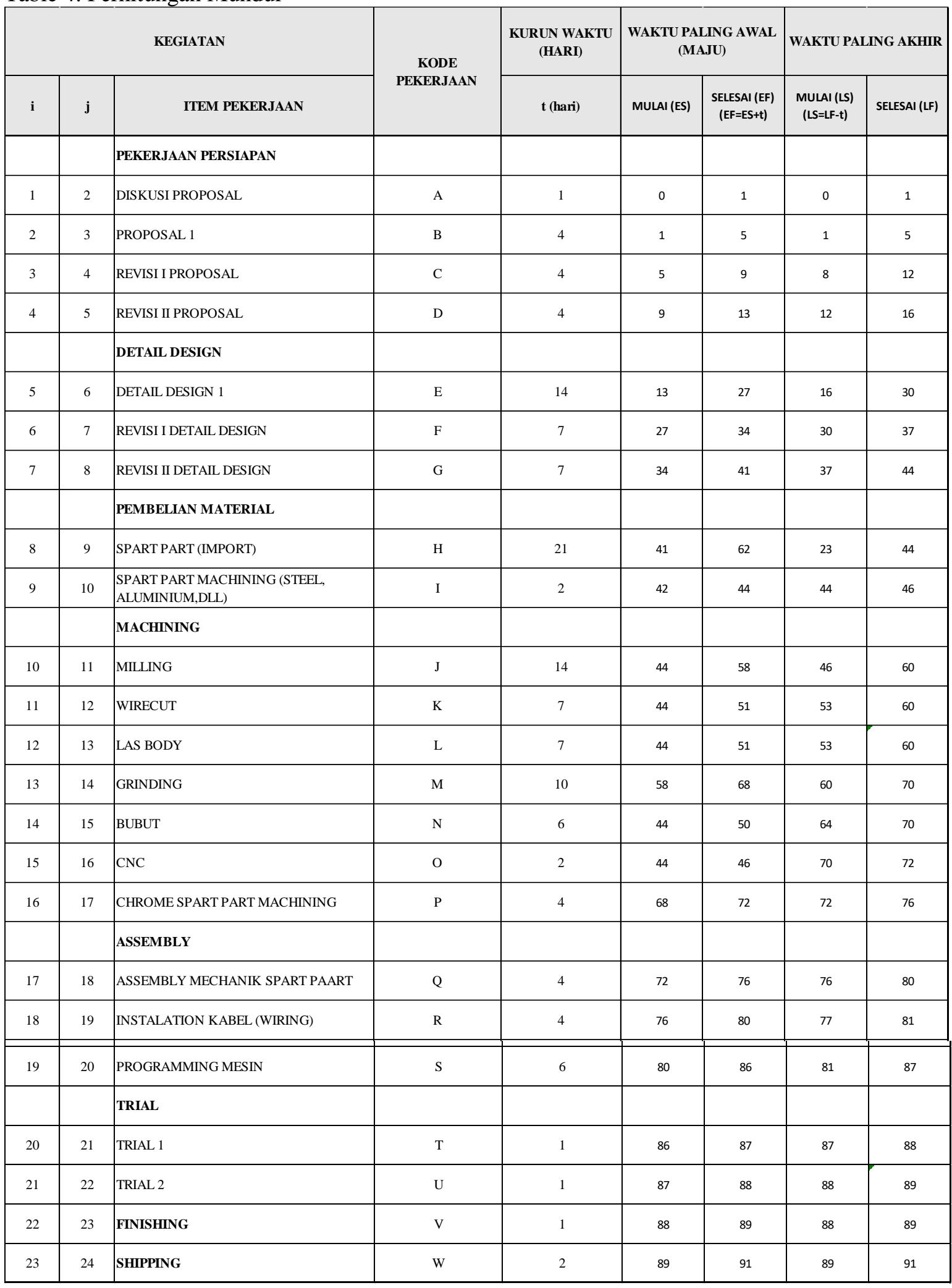

Tabel 4.adalah tabel perhitungan mundur, contoh perhitungan mundur adalah operasi terakhir dimana dimulai dari kegiatan dari proyek pada jaringan kegiatan. Dimulai pada aktivitas L dan keterlambatan aktivitas selesai
(LF) adalah hari kerja, keterlamabatan aktivitas selesai (LS) untuk aktivitas adalah 89 hari kerja (LS = LF -t atau LS = 91 - 2 = 89). LS untuk aktivitas L menjadi LF untuk aktivitas K. Selanjutnya kegiatan tersebut dapat 
digambarkan dalam suatu bentuk diagram jarigan kerja pada Gambar 4 berikut ini:

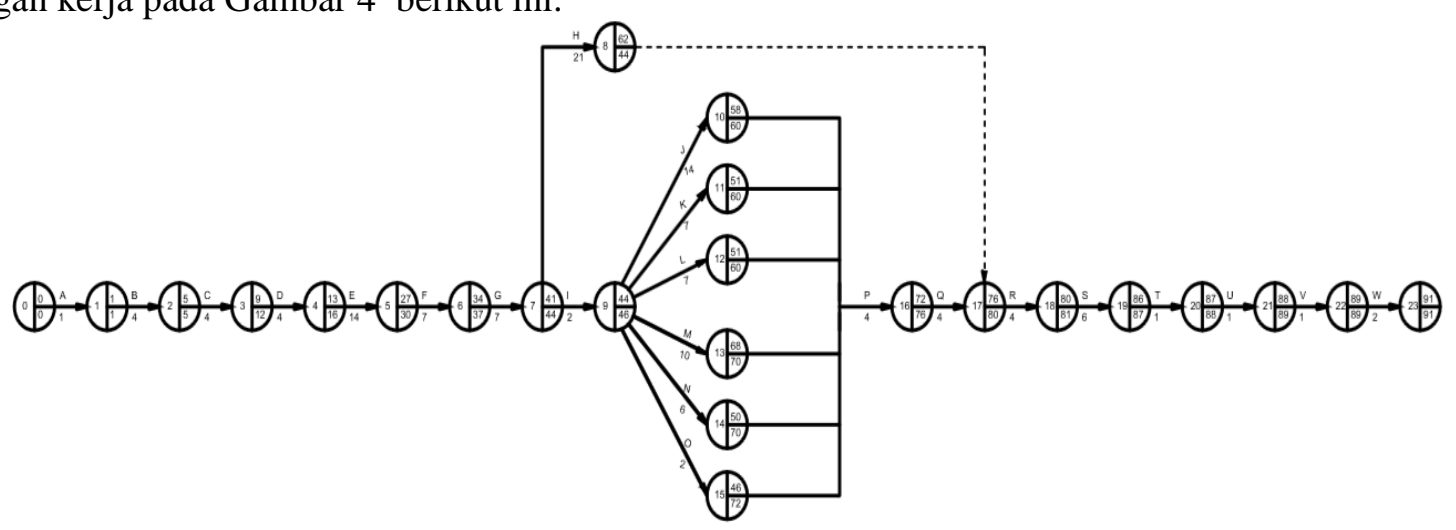

Gambar 4. Network perhitungan maju proyek mesin auto assembly membrane regulator valve

\section{Perhitungan Kelonggaran Waktu (Slack)}

Setelah perhitungan maju dan perhitungan mundur selesai dilakukan, maka berikutnya harus dilakukan perhitungan kelonggaran waktu dari kegiatan, yang terdiri dari slack dan free slack. Slack adalah waktu penyelesaian suatu kegiatan yang dapat diundur tanpa mempengaruhi saat paling cepat dari penyelesaian proyek secara keseluruhan. Perhitungan slack dapat mempergunakan persamaan : LS dan ES, yaitu $(\mathrm{LS}-\mathrm{ES}=\mathrm{SL})$

Table 4 .Perhitungan Kelonggaran Waktu (Slack)

\begin{tabular}{|c|c|c|c|c|c|c|c|c|c|}
\hline \multicolumn{3}{|r|}{ KEgiatAN } & \multirow{2}{*}{$\begin{array}{c}\text { KODE } \\
\text { PEKERJAAN }\end{array}$} & \multirow{2}{*}{$\begin{array}{c}\begin{array}{c}\text { KURUN WAKTU } \\
\text { (HARI) }\end{array} \\
\mathbf{t} \text { (hari) }\end{array}$} & \multicolumn{2}{|c|}{$\begin{array}{c}\text { WAKTU PALING AWAL } \\
\text { (MAJU) }\end{array}$} & \multicolumn{2}{|c|}{ WAKTU PALING AKHIR } & \multirow{2}{*}{$\begin{array}{l}\text { SLACK } \\
\text { (SL = LS-ES) }\end{array}$} \\
\hline $\mathrm{i}$ & $\mathrm{j}$ & ITEM PEKERJAAN & & & MULAI (ES) & $\begin{array}{c}\text { SELESAI (EF) } \\
(E F=E S+t)\end{array}$ & $\begin{array}{c}\text { MULAI (LS) } \\
\text { (LS=LF-t) }\end{array}$ & SELESAI (LF) & \\
\hline & & PEKERJAAN PERSIAPAN & & & & & & & \\
\hline 1 & 2 & DISKUSI PROPOSAL & A & 1 & 0 & 1 & 0 & 1 & 0 \\
\hline 2 & 3 & PROPOSAL 1 & B & 4 & 1 & 5 & 1 & 5 & 0 \\
\hline 3 & 4 & REVISI I PROPOSAL & $\mathrm{c}$ & 4 & 5 & 9 & 8 & 12 & 3 \\
\hline 4 & 5 & REVISI II PROPOSAL & D & 4 & 9 & 13 & 12 & 16 & 3 \\
\hline & & DETAIL DESIGN & & & & & & & \\
\hline 5 & 6 & DETAIL DESIGN 1 & E & 14 & 13 & 27 & 16 & 30 & 3 \\
\hline 6 & 7 & REVISI I DETAIL DESIGN & F & 7 & 27 & 34 & 30 & 37 & 3 \\
\hline 7 & 8 & REVISI II DETAIL DESIGN & G & 7 & 34 & 41 & 37 & 44 & 3 \\
\hline & & PEMBELIAN MATERIAL & & & & & & & \\
\hline 8 & 9 & SPART PART (IMPORT) & H & 21 & 41 & 62 & 23 & 44 & -18 \\
\hline 9 & 10 & $\begin{array}{l}\text { SPART PART MACHINING (STEEL, } \\
\text { ALUMINIUM,DLL) }\end{array}$ & I & 2 & 42 & 44 & 44 & 46 & 2 \\
\hline & & MACHINING & & & & & & & \\
\hline 10 & 11 & MILLING & $\mathrm{J}$ & 14 & 44 & 58 & 46 & 60 & 2 \\
\hline 11 & 12 & WIRECUT & $\mathrm{K}$ & 7 & 44 & 51 & 53 & 60 & 9 \\
\hline 12 & 13 & LAS BODY & $\mathrm{L}$ & 7 & 44 & 51 & 53 & 60 & 9 \\
\hline 13 & 14 & GRINDING & м & 10 & 58 & 68 & 60 & 70 & 2 \\
\hline 14 & 15 & BUBUT & $\mathrm{N}$ & 6 & 44 & 50 & 64 & 70 & 20 \\
\hline
\end{tabular}




\begin{tabular}{|c|c|l|c|c|c|c|c|c|c|}
\hline 15 & 16 & lNC & O & 2 & 44 & 46 & 70 & 72 & 26 \\
\hline 16 & 17 & CHROME SPART PART MACHINING & P & 4 & 68 & 72 & 72 & 76 & 4 \\
\hline & & ASSEMBLY & & & & & & & \\
\hline 17 & 18 & ASSEMBLY MECHANIK SPART PAART & $\mathrm{Q}$ & 4 & 72 & 76 & 76 & 80 & 4 \\
\hline 18 & 19 & INSTALATION KABEL (WIRING) & $\mathrm{R}$ & 4 & 76 & 80 & 77 & 81 & 1 \\
\hline 19 & 20 & PROGRAMMING MESIN & $\mathrm{S}$ & 6 & 80 & 86 & 81 & 87 & 1 \\
\hline & & TRIAL & & & & & & & 0 \\
\hline 20 & 21 & TRIAL1 & T & 1 & 86 & 87 & 87 & 88 & 1 \\
\hline 21 & 22 & TRIAL2 & V & 1 & 87 & 88 & 88 & 89 & 1 \\
\hline 22 & 23 & FINISHING & W & 2 & 89 & 91 & 89 & 91 & 0 \\
\hline 23 & 24 & SHIPPING & & & & 89 & 88 & 89 & 0 \\
\hline
\end{tabular}

Tabel 5 merupakan tabel perhitungan slack sesuai dengan persamaan diatas, sebagai contoh perhitugan slack untuk kegiatan B adalah 0 , yang mana $(14-14=0)$

\section{Perhitungan Kelonggaran Waktu (Free Slack)}

Kegiatan dengan free slack adalah unik karena kegiatan dapat ditunda tanpa menunda

ES dari kegiatan yang mengikutinya. Free slack menggambarkan perbedaan antara EF dari sebuah kegiatan dan ES dari kegiatan yang mengikutinya. Perhitungan free slack dapat mempergunakan persamaan : $\mathrm{LF}$ dan $\mathrm{EF}$, yaitu $(\mathrm{LF}-\mathrm{EF}=\mathrm{SL})$

Table 5. Perhitungan Kelonggaran Waktu (Free Salck)

\begin{tabular}{|c|c|c|c|c|c|c|c|c|c|c|}
\hline & & KEGiATAN & & $\begin{array}{c}\text { KURUN WAKTU } \\
\text { (HARI) }\end{array}$ & $\underset{(\mathrm{M}}{\text { WAKTUP }}$ & $\begin{array}{l}\text { UNG AWAL } \\
\text { (JU) }\end{array}$ & WAKTU PA & LNG AKHIR & & FREE SLACK \\
\hline $\mathrm{i}$ & $\mathrm{j}$ & TTEM PEKERJAAN & FENEKJAAN & $t$ (hari) & MULA| (ES) & $\begin{array}{l}\text { SEIESA) (EF) } \\
\text { (EF=ES+E) }\end{array}$ & 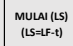 & SELESA (LF) & (SLL=LS-ES) & 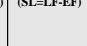 \\
\hline & & PEKERJAAN PERSIAPAN & & & & & & & & \\
\hline 1 & 2 & DISKUSI PROPOSAL & A & 1 & 0 & 1 & 0 & 1 & 0 & 0 \\
\hline 2 & 3 & PROPOSAL 1 & в & 4 & 1 & 5 & 1 & 5 & 0 & 0 \\
\hline 3 & 4 & REVISI I PROPOSAL & c & 4 & 5 & 9 & 8 & 12 & 3 & 3 \\
\hline 4 & 5 & REVISI II PROPOSAL & D & 4 & 9 & 13 & 12 & 16 & 3 & 3 \\
\hline & & DETALL DESIGN & & & & & & & & \\
\hline 5 & 6 & DETALL DESIGN 1 & E & 14 & ${ }^{13}$ & 27 & 16 & ${ }_{30}$ & 3 & 3 \\
\hline 6 & 7 & REVISI I DETALL DESIGN & $\mathrm{F}$ & 7 & 27 & 34 & ${ }_{30}$ & 37 & 3 & 3 \\
\hline 7 & 8 & REVISI II DETALL DESIGN & G & 7 & ${ }^{34}$ & 41 & 37 & 44 & 3 & 3 \\
\hline & & PEMBELIAN MATERIAL & & & & & & & & \\
\hline 8 & 9 & SPART PART (IMPORT) & $\mathrm{H}$ & 21 & ${ }^{41}$ & 62 & 23 & ${ }^{44}$ & -18 & -18 \\
\hline 9 & 10 & $\begin{array}{l}\text { SPART PART MACHINING (STEEL, } \\
\text { ALUMINIUM,DLL) }\end{array}$ & I & 2 & 42 & 44 & 44 & 46 & 2 & 2 \\
\hline & & MACHINING & & & & & & & & \\
\hline 10 & 11 & MILLNG & $\mathrm{J}$ & 14 & 44 & 58 & 46 & 60 & 2 & 2 \\
\hline 11 & 12 & WIRECUT & $\mathrm{K}$ & 7 & 44 & 51 & 53 & ${ }^{\infty}$ & 9 & ${ }^{9}$ \\
\hline 12 & 13 & LAS BODY & $\mathrm{L}$ & 7 & ${ }^{44}$ & 51 & 53 & ${ }^{60}$ & 9 & 9 \\
\hline 13 & 14 & GRINDING & M & 10 & 58 & 68 & 60 & 70 & 2 & ${ }^{2}$ \\
\hline 14 & 15 & BUBUT & $\mathrm{N}$ & 6 & 44 & 50 & 64 & 70 & 20 & 20 \\
\hline 15 & 16 & $\mathrm{CNC}$ & $\mathrm{o}$ & 2 & 44 & 46 & 70 & 72 & 26 & 26 \\
\hline 16 & 17 & CHROME SPART PART MACHINING & $\mathrm{P}$ & 4 & 68 & 72 & 72 & 76 & 4 & 4 \\
\hline & & ASSEMBLY & & & & & & & & \\
\hline 17 & 18 & ASSEMBLY MECHANIK SPART PAART & Q & 4 & 72 & 76 & 76 & 80 & 4 & 4 \\
\hline 18 & 19 & INSTALATION KABEL(WIRING) & $\mathrm{R}$ & 4 & 76 & 80 & 77 & 81 & 1 & 1 \\
\hline 19 & 20 & PROGRAMMING MESIN & $\mathrm{s}$ & 6 & 80 & 86 & 81 & 87 & 1 & 1 \\
\hline & & TRIAL & & & & & & & 0 & 0 \\
\hline 20 & 21 & TRIAL 1 & $\mathrm{~T}$ & 1 & 86 & 87 & 87 & 88 & 1 & 1 \\
\hline 21 & 22 & TRIAL2 & $\mathrm{u}$ & 1 & 87 & 88 & 88 & 89 & 1 & 1 \\
\hline 22 & 23 & FINISHING & $\mathrm{v}$ & 1 & ${ }^{88}$ & 89 & 88 & 89 & 0 & 0 \\
\hline 23 & 24 & SHIPPING & w & 2 & 89 & 91 & 89 & 91 & 0 & 0 \\
\hline
\end{tabular}


Tabel 6 merupakan tabel perhitungan free slack sesuai dengan persamaan diatas, sebagai contoh perhitungan free slack untuk aktivitas B adalah 0 , yang mana $(5-5=0)$.

\section{Jalur Lintasan Kritis}

Jalur lintasan kritis dalam proyek ini telah diketahui dari hasil perhitungan kelonggaran Table 6. Jalur Lintasan Kritis waktu slack dan free slack yang telah didapatkan hasilnya dalam tabel 6 dan tabel 7 . Slack dan free slack total yang mendapatkan hasil sama dengan nol (0), itu merupakan jalur lintasan kritis yang perlu diberikan prioritas dalam mengalokasikan kebutuhan kegiatan proyek. Adapun tebel jalur lintasan kritis tersebut sebagai berikut :

\begin{tabular}{|c|c|c|c|c|c|c|c|c|c|c|c|}
\hline \multicolumn{3}{|r|}{ KEGATAN } & \multirow{2}{*}{$\begin{array}{c}\text { KODE } \\
\text { PERERJAAN }\end{array}$} & \multirow{2}{*}{\begin{tabular}{|c}
$\begin{array}{c}\text { KURUN WAKTU } \\
\text { (HARI) }\end{array}$ \\
t(hari)
\end{tabular}} & \multicolumn{2}{|c|}{$\begin{array}{c}\text { WAKTU PALING AWAL } \\
\text { (MAJU) }\end{array}$} & \multicolumn{2}{|c|}{ WAKTU PAUNG AKHIR } & \multirow{2}{*}{$\underset{(S L=L S-E S)}{S}$} & \multirow{2}{*}{$\begin{array}{c}\text { FREF SLACK } \\
\text { (SI=LF-EF) }\end{array}$} & \multirow{2}{*}{ KETERANGAN } \\
\hline i & j & ITEMI PEKERJAAN & & & MULAI(ES) & $\begin{array}{l}\text { SLESSA)(EF) } \\
\text { (EF=[S+tZ) }\end{array}$ & $\begin{array}{l}\text { MULA) (LS) } \\
\text { (LS=LF-t) }\end{array}$ & Satsal(LF) & & & \\
\hline & & PEKERJAAN PERSIAPAN & & & & & & & & & \\
\hline 1 & 2 & DISKUSI PROPOSAL & A & 1 & 0 & 1 & 0 & 1 & 0 & 0 & laribs \\
\hline 2 & 3 & PROPOSAL 1 & B & 4 & 1 & s & 1 & s & 0 & 0 & leritis \\
\hline 3 & 4 & REVISII PROPOSAL & c & 4 & 5 & 9 & 8 & 12 & 3 & 3 & Wakw Luang \\
\hline \multirow[t]{2}{*}{4} & 5 & REVISI II PROPOSAL & D & 4 & 9 & 13 & 12 & 16 & 3 & 3 & Wakw Luang \\
\hline & & DETAII DESIGN & & & & & & & & & \\
\hline 5 & 6 & DETAII DESIGN 1 & E & 14 & 13 & 27 & 16 & 30 & 3 & 3 & Wakw Luang \\
\hline 6 & 7 & REVISII DETAIL DESIGN & F & 7 & 27 & 34 & 30 & 37 & 3 & 3 & Wakw Luang \\
\hline \multirow[t]{2}{*}{7} & 8 & REVISI II DETAII DESIGN & G & 7 & 34 & 41 & 37 & 44 & 3 & 3 & Wakw Luang \\
\hline & & PEMBELIAN MATERIAL & & & & & & & & & \\
\hline 8 & 9 & SPART PART (IMPORT) & н & 21 & 41 & 62 & 23 & 44 & -18 & -18 & leribs \\
\hline \multirow[t]{2}{*}{9} & 10 & $\begin{array}{l}\text { SPART PARTMACHNING (STEEL, } \\
\text { ALUMNIUMDLL) }\end{array}$ & I & 2 & 42 & 44 & 44 & 46 & 2 & 2 & Waktu Luang \\
\hline & & MACHINING & & & & & & & & & \\
\hline 10 & 11 & MLING & $\mathrm{J}$ & 14 & 44 & $s 8$ & 46 & 60 & 2 & 2 & Wakw Luang \\
\hline 11 & 12 & WIRECUT & $\mathrm{x}$ & 7 & 44 & 51 & 53 & 60 & 9 & 9 & Waktw Luang \\
\hline 12 & 13 & LAS BODY & L & 7 & 44 & s1 & 53 & 60 & 9 & 9 & Wakw Luang \\
\hline 13 & 14 & GRINDNG & $\mathrm{M}$ & 10 & 58 & $\Leftrightarrow$ & 60 & 70 & 2 & 2 & Wakw Luang \\
\hline 14 & 15 & BUBUT & $\mathrm{N}$ & 6 & 44 & so & 64 & 70 & 20 & 20 & Wakw Luang \\
\hline 15 & 16 & CNC & $\circ$ & 2 & 44 & $\Delta 6$ & 70 & 72 & 26 & 26 & Wakw Lueng \\
\hline \multirow[t]{2}{*}{16} & 17 & CHROME SPART PARTMACHINING & p & 4 & $\infty$ & 72 & 72 & 76 & 4 & 4 & Waktu Luang \\
\hline & & ASSEMBLY & & & & & & & & & \\
\hline 17 & 18 & ASSEMBL Y MECHANIK SPART PAART & Q & 4 & 72 & $x$ & 76 & 80 & 4 & 4 & Wakts Luang \\
\hline 18 & 19 & INSTALATON KABEL (MIRING) & R & 4 & 76 & $\infty$ & $n$ & 81 & 1 & 1 & Wakw Luang \\
\hline \multirow[t]{2}{*}{19} & 20 & PROGRAMMNG MESIN & s & 6 & $\infty$ & $\$$ & 81 & 87 & 1 & 1 & Wakw Luang \\
\hline & & TRLAL & & & & & & & & & \\
\hline 20 & 21 & TRIAL 1 & $\mathrm{~T}$ & 1 & $\$$ & 87 & 87 & 88 & 1 & 1 & Waktw Luang \\
\hline 21 & 22 & TRIAL 2 & $\mathrm{u}$ & 1 & 87 & $\$$ & 88 & 89 & 1 & 1 & Waktu Luang \\
\hline 22 & 23 & FINISHING & $\mathrm{v}$ & 1 & $\$$ & $\approx$ & 88 & 89 & 0 & 0 & leritis \\
\hline 23 & 24 & SHIPPING & $\mathrm{w}$ & 2 & 9 & 91 & 89 & 91 & 0 & 0 & bribs \\
\hline
\end{tabular}

Selanjutnya kegiatan jalur kritis tabel 8 tersebut dapat digambarkan dalam suatu bentuk diagram jarigan kerja pada Gambar 5 berikut ini : 


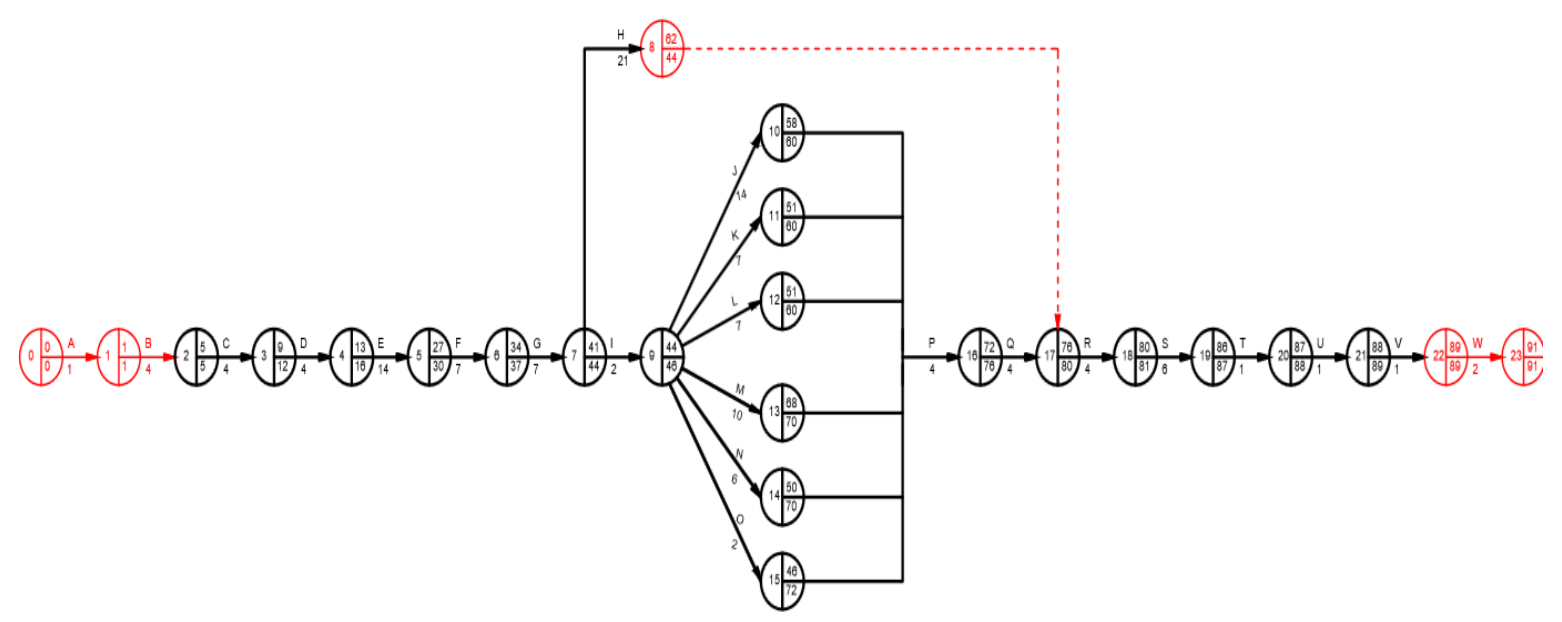

Gambar 5. Jalur Lintasan Kritis

\section{KESIMPULAN DAN SARAN Kesimpulan}

Dari hasil pengolahan data dan Analisa data yang telah dilakukan maka dapat diambil beberapa kesimpulan sebagai berikut:

1. Waktu penyelesaian proyek mesin Auto Assembly Membrane Regulator Valve Di PT. OMG dengan menggunakan metode CPM membutuhkan waktu 91 hari dari sebelumnya 133 hari, ini artinya lebih cepat 42 hari atau lebih cepat $31,5 \%$ untuk pengerjaan proyek mesin Auto Assembly Membrane Regulator Valve.

2. Kegiatan yang termasuk kegiatan kritis pada proyek mesin Auto Assembly Membrane Regulator Valve sebagai berikut:
a. Diskusi proposal dengan durasi waktu 1 hari
b. Pengerjaan proposal 1 dengan durasi waktu 4 hari
c. Pembelian spare part (import) dengan durasi waktu 21 hari
d. Machine Finishing dengan durasi waktu 1 hari
e. Shipping dengan durasi waktu 2 hari

\section{Saran}

1. PT. Oto Makmur Gemilang (OMG) belum memiliki asumsi dalam percepatan proyek dengan metode tertentu. CPM ini merupakan salah satu metode yang dapat digunakan oleh PT. Oto Makmur Gemilang (OMG) dalam percepatan proyek.

2. Berdasarkan pada kesimpulan yang diperoleh, kegiatan kritis bisa diminimalisir dengan menggabungkan kegiatan-kegiatan serupa untuk meminimalisir waktu penyelesaian proyek secara keseluruhan

\section{DAFTAR PUSTAKA}

Luthan, Lynna, P dan Syafriadi. 2006. Aplikasi Microsoft Project Untuk penjadwalan kerja proyek Teknik sipil. Yogyakarta : Penerbit ANDI

Yusron Arif, Achmad . 2018. 20 Pengertian Manajemen Menurut Para Ahli dan Pakar. diakses pada https://rocketmanajemen.com/20definisi-manajemen-menurut-paraahli/\#a

Yudaneru. 2017. Tugas Tentang Purchasing. diakses pada https://yudaneru.wordpress.com/2017/0 4/14/tugas-tentang-purchasing/

Schwalbe, K. 2007. Information Technology Project Management, Thomson Course Technology, edisi 5.

Husein, A. 2009. Manajemen Proyek. Andi Offset, Yogyakarta : Graha ilmu

Haming, murdifin dan Mahfud nurnajamuddin. 2011. Manajemen produksi modern. Jakarta: Bumi Aksara

Suharto, iman. 1999. Manajemen proyek (dari konseptual sampai operasional): konsep, studi kelayakan dan jaringan kerja edisi 2. Jakarta : erlangga.

Nurhayati.2010. manajemen proyek. Yogyakarta : Graha ilmu

Dimyati, H. nurjaman, K. soetari E. 2014. Manajemen proyek. Bandung : CV Pustaka Setia

Wiedhata A.S., Abdirama. 2017. S1 Thesis:Optimalisasi Pendjadwalan 
Pekerjaan Pembangunan Proyek Yodya Karya Tower Untuk Menghindari Keterlambatan Dengan Metode Cpm (Critical Path Method) Pada Studi Kasus Di Pt. Wijaya Karya. (Persero) Tbk. Jakarta : Universitas Mercu Buana
Heizer, H., Render. 2006. Operation management, pearson/prentice Hall

Gray, C.F., \& Larson, E.W. (2006). Project management, Mc-Graw Hill compani 